\title{
TINJAUAN KRIMINOLOGI TERHADAP PELAKU TINDAK PIDANA TERORISME DI INDONESIA DALAM PERSPEKTIF TEORI DIFFERENTIAL ASSOCIATION
}

\author{
Deny Guntara \\ Budiman
}

\section{Universitas Buana Perjuangan Karawang}

Email: deny.guntara@ubpkarawang.ac.id

Hk15.Budiman@mhs.ubpkarawang.ac.id

\begin{abstract}
Abstrak
Terorisme adalah suatu faham bahwa penggunaan cara-cara kekerasan dan menimbulkan ketakutan adalah cara yang sah untuk mencapai tujuan. Teori-teori kriminologi dapat digunakan untuk menganalisis permasalahan-permasalahan yang terkait dengan kejahatan atau penyebab kejahatan termasuk tindak pidana terorisme. Dalam penelitian ini yang menjadi batasan permasalahan akan ditinjau dari salah satu teori kriminologi dalam perspektif sosial yaitu Teori Differential Association. Teori ini merupakan teori yang menganggap bahwa tidak ada tingkah laku yang diturunkan berdasarkan pewarisan dari orang tuanya. Pola perilaku jahat tidak diwariskan, tetapi dipelajari melalui pergaulan. Tingkah laku jahat dipelajari dalam kelompok melalui interaksi dan komunikasi, dan yang dipelajari dalam kelompok. Ini adalah teknik untuk melakukan kejahatan serta alasan yang mendukung perbuatan jahat. Faktor orang melakukan tindak pidana terorisme ditinjau dari teori ini diantaranya faktor ideologi, faktor ketidakpuasan terhadap politik pemerintahan, faktor ekonomi, faktor kesenjangan sosial, faktor sosial dan budaya, pemahaman dan penafsiran ajaran agama yang tekstual, problem ideologi agama, kecenderungan salafisme. Upaya penanggulangan tindak pidana terorisme adalah melalui dua upaya yaitu upaya internal yang terdiri dari penegakan hukum, pembentukan Badan Nasional Penanggulangan Terorisme (BNPT), sinergitas kelembagaan, penerapan deradikalisasi, penerapan kontra radikalisasi, membentuk gerakan milenial anti radikalisme, dan strategi pemerintah lainnya, sedangkan upaya eksternal yaitu suatu upaya atau bentuk kerjasama antar negara terkait program penanggulangan tindak pidana terorisme khususnya di Indonesia.
\end{abstract}

Kata Kunci: Terorisme, Kriminologi, Teori

Differential Association

\begin{abstract}
Terrorism is a belief that understanding the use of methods of violence and causing fear is a legitimate way to achieve goals. Criminology theories can be used to analyze problems related to crime or causes of crime including terrorism. In this study, the limitation of the problem will be reviewed from one of the criminological theories in the social perspective, namely the Defferential Association Theory. This theory is a theory that assumes that there is no inherited behavior based on inheritance from their parents. The pattern of evil behavior is not inherited, but is learned through association. Bad behavior is learned in groups through interaction and communication, and learned in groups. This is a technique for committing crimes and reasons that support evil deeds. Factors of people committing criminal acts of terrorism in terms of this theory include ideological factors, factors of dissatisfaction with government politics, economic factors, social inequality factors, social and cultural factors, understanding and interpretation of textual religious teachings, religious ideological problems, salafism tendencies. The efforts to combat terrorism are through two efforts, namely internal efforts consisting of law enforcement, the establishment of the National Counterterrorism Agency (BNPT), institutional synergy, the application of deradicalisation, the application of counter-radicalization, forming millennial anti-radicalism movements, and other government strategies. Whereas external efforts are an effort or form of cooperation between countries related to terrorism crime prevention programs, especially in Indonesia.
\end{abstract}

Keyword: Terrorism, Criminology, Differential

Association Theory 
TINJAUAN KRIMINOLOGI TERHADAP PELAKU TINDAK PIDANA TERORISME DI INDONESIA DALAM PERSPEKTIF TEORI DIFFERENTIAL ASSOCIATION: Deny Guntara dan Budiman

\section{PENDAHULUAN}

Tindak Pidana Terorisme adalah suatu tindak pidana atau kejahatan luar biasa (Extra Ordinary Crime) yang menjadi perhatian dunia sejak lama sampai dengan sekarang ini termasuk di Indonesia, selain itu terorisme juga

merupakan kejahatan terhadap kemanusiaan (Crime Against Humanity), serta merupakan ancaman serius terhadap kedaulatan setiap negara karena terorisme sudah merupakan kejahatan yang bersifat internasional yang

menimbulkan bahaya terhadap keamanan, perdamaian dunia serta merugikan kesejahteraan masyarakat yang perlu dilakukan pemberantasan secara terencana dan berkesinambungan sehingga hak asasi orang banyak dapat dilindungi dan dijunjung tinggi.

Terorisme bukanlah hal yang baru dalam isu internasional, tetapi menjadi aktual kembali terutama sejak terjadinya peristiwa pengeboman terhadap gedung World Trade Center (WTC) di New York, Amerika Serikat pada tanggal 11 September 2001 yang disusul kemudian dengan kampanye Amerika Serikat melawan terorisme global (Global War on Terrorism). Kejadian ini merupakan isu global yang mempengaruhi kebijakan politik seluruh negara-negara di dunia, sehingga menjadi titik tolak persepsi untuk memerangi terorisme sebagai musuh internasional.

Kejahatan terorisme seperti itu juga telah terjadi di Indonesia dan juga telah memakan banyak korban jiwa baik warga negara Indonesia sendiri maupun warga negara asing. Seperti yang tercantum dalam sebuah sumber yang menyatakan bahwa aksi peledakan bom bunuh diri pada tanggal 12 Oktober 2002 pada saat terjadi peledakan bom di Legian, Bali, yang menyebabkan Indonesia menjadi fokus publik internasioanal. Peristiwa ini terjadi pada tanggal 12 Oktober 2002, atau biasa dikenal dengan peristiwa Bom Bali I. Pada peristiwa Bom Bali I, ledakan terjadi di dua tempat berbeda, yakni Paddy ${ }^{\text {ee }}$ Cafe dan Sari Club, Legian. Peristiwa tersebut menewaskan 202 orang, dan 88 diantaranya adalah warga

Australia.Terorisme adalah suatu pemikiran dimana penggunaan cara-cara kekerasan dan menimbulkan ketakutan adalah cara yang sah untuk mencapai tujuan. Istilah teroris oleh para ahli kontra terorisme dikatakan merujuk kepada para pelaku yang tidak tergabung 
dalam angkatan bersenjata yang dikenal atau tidak menuruti peraturan angkatan bersenjata tersebut. ${ }^{1}$

Tindak Pidana Terorisme yang terjadi di Indonesia akhir-akhir ini mempunyai keterkaitan dengan ideologi, sejarah dan politik serta merupakan bagian dari dinamika lingkungan strategis pada tataran regional maupun global. Masyarakat Indonesia saat ini sedang dihadapkan dengan keadaan yang sangat mengkhawatirkan akibat maraknya aksi teror. Bagi Indonesia telah merasakan betapa besarnya kerugian akibat aksi teror ini, karena telah menimbulkan korban nyawa warga negara Indonesia dalam jumlah cukup kerugian harta benda dan memperparah keadaan ekonomi bangsa yang sedang

terpuruk akibat krisis yang berkepanjangan.

Teori Kriminologi dapat digunakan untuk menganalisis permasalahanpermasalahan yang terkait dengan kejahatan atau penyebab kejahatan termasuk tindak pidana terorisme. Teori-teori kriminologi pada hakikatnya berusaha untuk mengkaji dan

\footnotetext{
1 Obsatar Sinaga, Terorisme kanan Indonesia dinamika dan penanggulangannya, Elex Media Komputindo, Jakarta, 2018, hlm. 10
}

menjelaskan hal-hal yang berhubungan dengan permasalahan penjahat dan kejahatan. Teori Defferential Association yang dikemukakan oleh Edwin $\mathrm{H}$. Sutherland menganggap bahwa tidak ada tingkah laku yang diturunkan berdasarkan pewarisan dari orang tuanya. Pola perilaku jahat tidak diwariskan, tetapi dipelajari melalui pergaulan yang akrab. Tingkah laku jahat dipelajari dalam kelompok melalui interaksi dan komunikasi, dan yang dipelajari dalam kelompok adalah teknik untuk melakukan kejahatan dan alasan yang mendukung perbuatan jahat. Dengan demikian penelitian ini yang terkait dengan pelaku tindak pidana terorisme akan ditinjau dari teori kriminologi dalam perspektif sosialnya. ${ }^{2}$ Berdasarkan uraian tersebut di atas, maka penulis tertarik untuk melakukan penelitian dengan judul "Tinjauan Kriminologi Terhadap Pelaku Tindak

Pidana Terorisme di Indonesia dalam Perspektif Teori Differential Association".

\footnotetext{
2 http://repository.ut.ac.id/4193/1/PKNI4209M1.pdf
} 


\section{PERMASALAHAN}

Berdasarkan hal-hal yang telah dijelaskan di atas, maka muncul suatu rumusan masalah yaitu sebagai berikut :

1. Apa saja faktor-faktor yang membentuk atau menimbulkan orang melakukan tindak pidana terorisme ditinjau dari Teori Defferential Association?

2. Bagaimana upaya penanggulangan tindak pidana terorisme di Indonesia?

\section{METODE PENELITIAN}

Metode pendekatan yang digunakan dalam penelitian ini adalah yuridis

normatif yaitu metode dengan menginventarisasi, mengkaji, dan meneliti data sekunder berupa peraturan perundang-undangan, asas-asas hukum, pengertian-pengertian hukum, kasus yang berkaitan dengan masalah yang akan penulis bahas yaitu berkaitan dengan Pelaku Tindak Pidana Terorisme di Indonesia.

Untuk mengkaji pokok permasalahan, penelitian ini mempergunakan metode penelitian hukum normatif. Dengan meneliti bahan pustaka yang ada. Salah satunya dengan pendekatan perundang-undangan, karena yang akan diteliti adalah berbagai aturan hukum yang menjadi fokus sekaligus tema sentral suatu penelitian. Penelitian ini akan lebih menitikberatkan pada penelitian hukum normatif, dengan menyesuaikan diri dengan ruang lingkup dan identifikasi masalah yang telah dikemukakan di atas. Pendekatan yang bersifat yuridis-normatif tersebut akan dilakukan dengan mempergunakan bahan hukum primer, bahan hukum sekunder dan bahan hukum tersier.

\section{HASIL DAN PEMBAHASAN}

\section{A. Faktor Yang Menyebabkan} Orang Melakukan Tindak Pidana Terorisme Ditinjau Dari Teori

\section{Defferential Association}

Terorisme merupakan tindak pidana yang unik, karena motif dan faktor penyebab dilakukannya tindak pidana ini sangat berbeda dengan motifmotif dari tindak pidan lain. Salahuddin wahid sebagaimana dikutip oleh Abdul Zulfikar Akaha mengatakan bahwa terorisme dapat di lakukan dengan berbagai motivasi, yaitu karena alasan agama, alasan idiologi, alasan untuk memperjuangkan kemerdekaan, alasan untuk membebaskan diri dari ketidakadilan, dan karena adanya 
TINJAUAN KRIMINOLOGI TERHADAP PELAKU TINDAK PIDANA TERORISME DI INDONESIA DALAM PERSPEKTIF TEORI DIFFERENTIAL ASSOCIATION: Deny Guntara dan Budiman

$$
\begin{aligned}
& \text { kepentingan tertentu. Dengan jelas, yaitu etnis atau bangsa } \\
& \text { kompleksnya motif dilakukanya }
\end{aligned}
$$$$
\text { terorisme,maka fenomena politik }
$$
kekerasan dan pengaturan terorisme tidak dapat dengan mudah dirumuskan sehingga tindak kekerasan itu dapat dilakukan oleh individu maupun

kelompok. Faktor penyebab dilakukannya tindak pidana ini sangat berbeda dengan dari tindak pidana lain, seperti tindak pidana pencucian uang, perdangan manusia, perdagangan narkoba secara illegal maupun perompakan laut dan perdanganan senjata Illegal. Menurut Bambang Pranowo, setidaknya ada 5 faktor penyebab terjadinya terorisme, yakni:

1. Kesukuan, nasionalisme/ separatism (Etnicity, nationalism/separatism)

Tindak teror ini terjadi di daerah yang dilanda konflik antar etnis/suku atau pada suatu bangsa yang ingin memerdekan diri. Menebar teror akhirnya digunakan pula sebagai satu cara untuk mencapai tujuan atau alat perjuangan. Sasarannya
2. Kemiskinan dan kesenjangan dan globalisasi (Poverty and economic disadvantage, globalisation)

Kemiskinan dan kesenjangan ternyata menjadi masalah sosial yang mampu memantik terorisme. Kemiskinan dapat dibedakan menjadi 2 macam: kemiskinannaturaldan kemiskinanstruktural.

Kemiskinan natural bisa dibilang "miskin dari asalnya", sedang kemiskinan struktural adalah kemiskinan yang dibuat. Hal ini terjadi ketika penguasa justru mengeluarkan kebijakan yang malah memiskinkan rakyatnya. Jenis kemiskinan kedua punya potensi lebih tinggi bagi munculnya terorisme.

3. Non demokrasi (non democracy)

Negara non demokrasi juga disinyalir sebagai tempat tumbuh suburnya terorisme. Di

\footnotetext{
3 Bambang Pranowo, Orang Jawa Jadi Teroris, Pustaka Alfabet, Jakarta, 2011, hlm. 5
} 
TINJAUAN KRIMINOLOGI TERHADAP PELAKU TINDAK PIDANA TERORISME DI INDONESIA DALAM PERSPEKTIF TEORI DIFFERENTIAL ASSOCIATION: Deny Guntara dan Budiman

negara demokratis, semua warga negara memiliki kesempatan untuk menyalurkan semua pandangan politiknya. Iklim demokratis menjadikan rakyat sebagai representasi kekuasaan tertinggi dalam pengaturan negara. Artinya, rakyat merasa dilibatkan dalam pengelolaan negara. Hal serupa tentu tidak terjadi di negara non demokratis. Selain tidak memberikan kesempatan partisipasi masyarakat, penguasa non demokratis sangat mungkin juga melakukan tindakan represif terhadap rakyatnya. Keterkungkungan ini menjadi kultur subur bagi tumbuhnya benih-benih terorisme.

4. Pelanggaran harkat kemanusiaan (Dehumanisation) Aksi teror akan muncul jika ada diskriminasi antar etnis atau kelompok dalam masyarakat. Hal ini terjadi saat ada satu kelompok diperlakukan tidak sama hanya karena warna kulit, agama, atau lainnya. Kelompok yang direndahkan akan mencari cara agar mereka didengar, diakui, dan diperlakukan sama dengan yang lain. Atmosfer seperti ini lagi-lagi akan mendorong berkembang biaknya teror.

5. Radikalisme agama (Religion) Butir ini nampaknya tidak asing lagi. Peristiwa teror yang terjadi di Indonesia banyak terhubung dengan sebab ini. Radikalisme agama menjadi penyebab unik karena motif yang mendasari kadang bersifat tidak nyata. Beda dengan kemiskinan atau perlakuan diskriminatif yang mudah diamati. Radikalisme agama sebagian ditumbuhkan oleh cara pandang dunia para penganutnya.

Pandangan lain dari faktor penyebab terjadinya tindak pidana terorisme adalah terdapat dua variabel penting yang membentuk gerakan-gerakan radikal dalam kalangan Islam, yaitu faktor intern dan ekstern. Faktor dari dalam lebih banyak berkaitan dengan penafsiran konsep jihad yang dipahami sebagai perang terhadap non Islam. Mereka selalu melihat dunia dengan dua 
sisi, muslim dan non muslim. Adapun faktor ekstern merupakan reaksi terhadap modernisasi yang dilakukan oleh barat terhadap dunia Islam. Pada konteks kekinian, radikalisme di kalangan sebagian penganut Islam didorong oleh kondisi sosial ekonomi internasional yang dianggap tidak adil bagi kaum muslimin.

Berawal dari dua sebab tersebut maka muncul gerakan terorisme di Indonesia. Ada dua faktor yang menyebabkan Indonesia dipilih untuk dijadikan sebagai sarang teroris, yaitu situasi politik pasca runtuhnya rezim orde baru membuka ruang begitu luas bagi berkembangnya radikalisme agama, dan yang kedua adalah lemahnya sistem kepemimpinan pemerintahan, seperti jatuhnya rezim orde baru merupakan tahapan pertama dari proses perkembangan demokrasi sedangkan tahapan kedua dan ketiga adalah masa transisi (pergantian) dan konsolidasi demokrasi (perundingan). Ada pandangan bahwa masa ini merupakan masa krisis karena demokrasi belum menemukan bentuk yang ideal sehingga momen inilah yang dimanfaatkan untuk menabur benih-benih terorisme di Indonesia. Adanya dua faktor di atas menjadikan tindakan-tindakan terorisme di Indonesia semakin mudah untuk dilakukan. Bagi pelaku aksi teroris, tindakan kekerasan yang seringkali membawa korban sipil tidak perlu diakui sebagai tindakan kejahatan melawan kemanusiaan apalagi melanggar hak asasi manusia dan bagaimana sesuatu itu dipelajari didalam lingkungan tersebut.

Dalam Teori Defferential Association menekankan bahwa semua tingkah laku itu dapat dipelajari dan ia mengganti pengertian mengenai social disorganization dengan differential social organization. Dengan demikian, maka teori ini menentang bahwa tidak ada tingkah laku (perilaku jahat) yang diturunkan atau diwariskan oleh kedua orang tua. Dengan kata lain, pola perilaku jahat tidak diwariskan oleh kedua orang tua akan tetapi perilaku jahat tersebut dipelajari melalui suatu pergaulan yang akrab.

Berkaitannya dengan ilmu kriminologi yang ditinjau dari teorinya Edwin Sutherland yaitu teori defferential association dimana di dalam teorinya Sutherland berpendapat bahwa perilaku kriminal merupakan perilaku yang dipelajari di dalam lingkungan sosial, artinya semua tingkah laku dapat 
dipelajari dengan berbagai cara. Oleh karena itu, perbedaan tingkah laku yang conform dengan criminal adalah apa dan bagaimana sesuatu itu dipelajari didalam lingkungan tersebut. Selain itu teori ini menentang bahwa tidak ada tingkah laku (perilaku jahat) yang diturunkan atau diwariskan oleh kedua orang tua. Dengan kata lain, pola perilaku jahat tidak diwariskan oleh kedua orang tua akan tetapi perilaku jahat tersebut dipelajari melalui suatu pergaulan yang akrab. Kemudian untuk lebih jelasnya mengenai teori differential association yang dikemukakan oleh Edwin Sutherland adalah sebagai berikut:

1. Perilaku kejahatan dipelajari;

2. Perilaku kejahatan dipelajari dalam interaksi dengan orang lain dari komunikasi;

3. Dasar pembelajaran perilaku jahat terjadi dalam kelompok pribadi yang intim;

4. Ketika perilaku jahat dpelajari, pembelajaran itu termasuk pula:

a. Teknik melakukan kejahatan, yang biasanya terlihat sangat sulit, dan juga sebaliknya terlihat sangat sederhana. b. Arah khusus dari motif, dorongan, rasionalisasi, dan sikap-sikap.

5. Arah khusus dari motif dan dorongan dipelajari dari defenisi aturan hukum yang menguntungkan atau tidak menguntungkan;

6. Seseorang menjadi menyimpang (delinkuen) disebabkan pemahaman terhadap definisidefinisi yang menguntungkan dari pelanggaran terhadap hukum melebihi defenisi-defenisi yang tidak menguntungkan untuk melangar hukum;

7. Asosiasi yang berbeda-beda mungkin beraneka ragam dalam frekuensi, lamanya, prioritas, dan intensitas;

8. Proses pembelajaran perilaku jahat melalui persekutuan dengan pola-pola kejahatan dan anti kejahatan meliputi seluruh mekanisme yang rumit dalam setiap pembelajarannya;

9. Walaupun perilaku jahat merupakan penjelasan dari kebutuhan-kebutuhan dan nilainilai umum, tetapi hal itu tidak dijelaskan oleh kebutuhan- 
TINJAUAN KRIMINOLOGI TERHADAP PELAKU TINDAK PIDANA TERORISME DI INDONESIA DALAM PERSPEKTIF TEORI DIFFERENTIAL ASSOCIATION: Deny Guntara dan Budiman

kebutuhan dan nilai-nilai umum tersebut. Karena perilaku non kriminal dapat tercermin dari kebutuhan-kebutuhan dan nilainilai umum yang sama.

Tindak pidana terorisme (peristiwa, pelaku, korban) merupakan suatu hasil kejahatan dimana kejahatan itu (perilaku jahat) dipelajari. Hasil analisis menyimpulkan bahwa tindak pidana terorisme merupakan suatu kejahatan yang di pelajari. Dilihat dari sisi peristiwa, pelaku, dan korban sangatlah berkaitan terhadap suatu kejahatan (perilaku jahat) itu dipelajari. Dari pernyataan ini peneliti berpendapat

bahwa ketika berbicara suatu perbuatan/tindak pidana secara umum unsur yang selalu melekat bersamaan dengan dimana perbuatan/tindak pidana itu dilakukan yaitu pertama, mengenai peristiwa dari tindak pidana itu sendiri, kedua, pelaku atau orang yang melakukan tindak pidana, dan ketiga korban yang dari tindak pidana itu sendiri yang secara umum tindak pidana terorisme dikategorikan sebagai suatu perbuatan/tindak pidana yang telah direncanakan dan dipelajari sebelumnya oleh pelaku tersebut.

\section{B. Upaya Penanggulangan Tindak Pidana Terorisme Di Indonesia}

Perundang-undangan tentang tindak pidana terorisme diatur oleh Pemerintah dengan dikeluarkannya Undang-Undang Nomor 15 Tahun 2003 tentang

Penetapan Peraturan Pemerintah Pengganti Undang-Undang Nomor 1 Tahun 2002 tentang Pemberantasan Tindak Pidana Terorisme menjadi Undang-Undang, dan perubahan terbaru dengan mengeluarkan Undang-Undang Nomor 5 Tahun 2018 tentang Perubahan atas Undang-Undang Nomor 15 Tahun 2003 tentang Penetapan Peraturan Pemerintah Pengganti Undang-Undang Nomor 1 Tahun 2002 tentang

Pemberantasan Tindak Pidana Terorisme menjadi Undang-Undang. Yakni peraturan tersebut berisi penjelasan tentang terorisme, tindak pidananya serta bagaimana cara

penanganan terorisme. Setelah diterbitkan hukum sebagai landasan program, maka yang dilakukan oleh

Pemerintah adalah melaksanakan Undang-undang tersebut.

Negara Indonesia secara serius sudah melakukan upaya-upaya penanggulangan terorisme, upaya penanggulangan dapat digolongkan ke 
TINJAUAN KRIMINOLOGI TERHADAP PELAKU TINDAK PIDANA TERORISME DI INDONESIA DALAM PERSPEKTIF TEORI DIFFERENTIAL ASSOCIATION: Deny Guntara dan Budiman

dalam dua cakupan yaitu internal dan eksternal. Upaya internal adalah upayaupaya penanggulangan terorisme yang dilakukan oleh pemerintah Indonesia tanpa melibatkan negara lain, sedangkan upaya eksternal adalah upaya penanggulangan terorisme yang dilakukan dengan negara lain baik dalam lingkup regional maupun lingkup internasional. Secara umum upaya internal yang dilakukan oleh Indonesia guna menanggulangi terorisme adalah sebagai berikut:

\section{Penegakan Hukum}

Salah satu prinsip pokok strategi penanggulangan terorisme Indonesia menurut Ketua BNPT adalah bahwa Pemerintah Indonesia memperlakukan aksi terorisme sebagai tindakan

kriminal, sehingga yang digunakan adalah pendekatan hukum. Penyelenggaraan penegakkan hukum terhadap tindak pidana terorisme diatur dalam Undang-Undang Nomor 5 Tahun 2018 tentang Perubahan Undang-Undang Nomor 15 Tahun 2003 tentang Pentapan Peraturan Pengganti UndangUndang Nomor 1 tahun 2002 tentang Pemberantasan Tindak

Pidana Terorisme menjadi Undang - Undang. Kemudian Undang-Undang Nomor 9 Tahun 2013 tentang Pencegahan dan Pemberantasan Tindak Pidana Pendanaan Terorisme. Secara umum, strategi penegakkan hukum ini dapat dikatakan masih menghadapi berbagai tantangan. Penegakan hukum terhadap sistem kejahatan terorisme dipandang masih lemah.

2. Pembentukan Badan Nasional Penanggulangan Teroris (BNPT) BNPT dibentuk melalui Peraturan Presiden Nomor 46 tahun 2010, yang kemudian diubah dengan Peraturan Presiden Nomor 12 tahun 2012. Pembentukan BNPT merupakan Kebijakan Nasional Penanggulangan Terorisme di Indonesia. Badan ini merupakan pengembangandariDesk

Koordinasi Pemberantasan Terorisme (DKPT) yang dibuat pada tahun 2002. BNPT juga dibentuk merupakan sebuah regulasi sebagai elaborasi Undang-Undang No. 34/2004 
TINJAUAN KRIMINOLOGI TERHADAP PELAKU TINDAK PIDANA TERORISME DI INDONESIA DALAM PERSPEKTIF TEORI DIFFERENTIAL ASSOCIATION: Deny Guntara dan Budiman

tentang TNI dan Undang-Undang

Nomor 2 Tahun 2002 tentang

POLRI, untuk mengatur

ketentuan lebih rinci tentang

"Rule of Engagement" (aturan

pelibatan) TNI, terkait tugas

operasi militer selain perang,

termasuk aturan pelibatan TNI

dalam mengatasi terorisme dan

tugas perbantuan TNI terhadap

Polri.

3. Sinergitas Kelembagaan

Demi menyongsong kehidupan bangsa dan negara yang aman dan damai, dalam penanggulangan tindak pidana terorisme perlu adanya sinergitas antar lembaga pemerintah maupun swasta yang ada kaitan dengan suatu pembangunan dalam roda pemerintahan, baik itu di pusat sampai daerah, hal ini demikian akan terciptanya suatu perubahan yang mendasar dan menangkal terkait paham-paham radikal yang selalu menghantui masyarakat luas.

\section{Deradikalisasi}

Deradikalisasi adalah bagian dari strategi kontra terorisme, deradikalisasi dipahami sebagai cara merubah ideologi kelompok teroris secara drastis. Deradikalisasi ditujukan untuk mengubah seseorang yang semula radikal menjadi tidak lagi radikal. Deradikalisasi terorisme diwujudkan dengan program reorientasi motivasi, reedukasi, resosialisasi, serta mengupayakan kesejahteraan sosial dan kesetaraan dengan masyarakat lain bagi mereka yang terlibat terorisme maupun bagi simpatisan.

Berdasarkan analisis diatas peneliti berpendapat bahwa upaya yang dilakukan pemerintah terbagi menjadi 2 (dua) hal yaitu pertama, upaya yang sifat nya substantif/prosedural dan kedua, upaya yang sifatnya fundamental/mendasar. Upaya yang harus dilakukan pemerintah saat ini adalah upaya yang sifatnya fundamental karena berkaitan dengan akar permasalahan yang terkandung dalam unsur-unsur tindak pidana terorisme agar mampu untuk menyelesaikan permasalahan secara tepat dan cepat. 


\section{KESIMPULAN}

Berdasarkan hasil penelitian dan pembahasan maka dapat disimpulkan penelitian ini bahwa Faktor orang melakukan tindak pidana terorisme ditinjau dari perspektif Teori Defferential Association diantaranya: Faktor ideologi; Faktor ketidakpuasan terhadap politik pemerintah; Faktor ekonomi; Faktor kesenjangan sosial; Faktor sosial dan budaya; Faktor pemahaman dan penafsiran ajaran agama yang tekstual; Faktor problem ideologi agama; Faktor kecenderungan salafisme. Selain itu upaya penanggulangan tindak pidana terorisme adalah melalui dua upaya yaitu upaya internal yang terdiri dari penegakan hukum, pembentukan Badan Nasional Penanggulangan Terorisme (BNPT), sinergitas kelembagaan, penerapan deradikalisasi, penerapan kontra radikalisasi, membentuk gerakan milenial anti radikalisme, dan strategi pemerintah lainnya. Sedangkan upaya eksternal yaitu suatu upaya atau bentuk kerjasama antar negara terkait program penanggulangan tindak pidana terorisme khususnya di Indonesia.

\section{DAFTAR PUSTAKA}

Alam

A.S, Pengantar

Kriminologi, Pustaka

Refleksi Books,

Makassar, 2010.

Bambang Abimanyu, Teror Bom

di Indonesia, Jakarta,

Grafindo, 2005.

Edwin H. Sutherland, Donald R.

Cressey, dan David F.

Luckenbill, Prinsip-

Prinsip

Dasar

Kriminologi, Prenada

Media Group, Jakarta,

2018.

Erdianto Effendi, Hukum Pidana

Indonesia Suatu

Pengantar, Refika

Aditama, Bandung,

2011.

Goenawan Parmadi, Fantasi

Terorisme, Mascom

Media, Semarang, 2003.

Indriyanto Seno Adji, Terorisme

dan HAM dalam

Terorisme, Tragedi

Umat Manusia,

Jakarta, 2001. 
TINJAUAN KRIMINOLOGI TERHADAP PELAKU TINDAK PIDANA TERORISME DI INDONESIA DALAM PERSPEKTIF TEORI DIFFERENTIAL ASSOCIATION: Deny Guntara dan Budiman

Mahrus Ali, Dasar-Dasar Hukum

Pidana, Sinar Grafika, 2011, Jakarta Timur.

Muladi, Demokrasi Hak Asasi

Manusia dan

Reformasi Hukum di

Indonesia, Habibie

Center, Jakarta, 2002. Obsatar

Sinaga, Terorisme kanan

Indonesia dinamika

dan

penanggulangannya,

Elex

Media

Komputindo, Jakarta, 2018.

P.A.F. Lamintang, Dasar-Dasar

Hukum Pidana

Indonesia, PT Citra

Aditya Bakti,

Bandung, 1997.

Rahman Syamsuddin dan Ismail

Aris, Merajut Hukum

Di Indonesia, Mitra

Wacana Media,

Jakarta, 2014.

Simandjuntak, B dan Chaidir Ali,

Cakrawala Baru

Kriminologi, Tarsito,

Bandung, 1980.

Soedjono Dirdjosisworo, Ruang

Lingkup

Kriminologi,
Remaja Karya,

Bandung, 1984.

Soerjono Soekanto, Faktor-Faktor

Yang Mempengaruhi

Penegakan Hukum,

PT. Raja Grafindo

Persada, Jakarta, 2010.

Tim Redaksi Nuansa Aulia, UUD

1945 Sebelum dan

Setelah Amandemen,

Nuansa Aulia,

Bandung, 2009.

Topo Santosa dan Eva Achjani

Zulfa, Kriminologi,

Raja Grafindo

Persada, Depok, 2017. Wibowo

Ari, Hukum Pidana Terorisme

Kebijakan

Formulatif Hukum

Pidana dalam

penanggulangan

Tindak Pidana

Terorisme di

Indonesia, Graha Ilmu,

Yogyakarta, 2012.

Yesmil Anwar dan Adang,

Kriminologi, $\quad$ PT

Reflika Aditama,

Bandung, 2010.

Zarisnov Arafat, Kriminologi

(Suatu pengantar 
TINJAUAN KRIMINOLOGI TERHADAP PELAKU TINDAK PIDANA TERORISME DI INDONESIA DALAM PERSPEKTIF TEORI DIFFERENTIAL ASSOCIATION: Deny Guntara dan Budiman

teoritik), FBIS Publising

(FBIS UBP Karawang),

Karawang, 2018. 